\title{
The impact of english as global language for trading between China and South American enterprises.
}

The impact of english as global language for trading between china and south american enterprises.

Edison Gerardo Llerena Medina. ${ }^{1}$

Recibido: 16-12-2017 / Revisado: 08-02-2018 Aceptado: 01-03-2018/ Publicado: 01-04-2018

\begin{abstract}
.
DOI: $\underline{\text { https://doi.org/10.33262/cienciadigital.v2i2.118 }}$

English is becoming the dominant language. Its goal is to enhance the fields around the planet bringing the American culture and literature, as well as participate in trading because English is so widely spoken, it has been referred as the "world language". Even though, it is not the official language in most countries, it is taught as a foreign language in many other countries. It is the language for maritime and aeronautics, medicine, research as well as the language for business used by international organizations and enterprises.
\end{abstract}

The objective of the article is to broadly analyze the relationships between Asian countries and Latin America, focusing on the tighten economic relationship between them countries during the last few years. Latin America has been a region traditionally under the US hegemony, but recently, it has awaken and is looking for further treatments with a China. This paper pretends to analyze the impact of the English Language which is used when signing up business treatments between them.

Keywords: business, Global Language, Trading agreements, Culture, communication

Resumen.

El inglés se está convirtiendo en el idioma dominante. Su objetivo es mejorar los campos en todo el planeta trayendo la cultura y la literatura estadounidense, así como

${ }^{1}$ Universidad Técnica de Ambato, Centro de Idiomas, Ecuador, eg.llerena @ uta.edu.ec 
participar en los negocios, porque el inglés es ampliamente hablado, se lo conoce como el "idioma mundial". Aunque no es el idioma oficial en la mayoría de los países, se lo enseña como idioma extranjero en muchos otros países. Es el lenguaje para la industria marítima y aeronáutica, medicina, investigación, así como el lenguaje para los negocios utilizado por organizaciones y empresas internacionales.

El objetivo del presente artículo es analizar ampliamente las relaciones entre los países asiáticos y América Latina, centrándose en la estrecha relación económica entre los países en los últimos años. América Latina ha sido tradicionalmente una región bajo la hegemonía estadounidense, pero recientemente ha despertado y está buscando nuevos tratados comerciales con China. Este documento pretende analizar el impacto del idioma inglés que se utiliza al registrar tratamientos comerciales entre ellos.

Palabras Claves: business, Global Language, Trading agreements, Culture. Communication

\section{Introducción.}

These days, Ostler (2005:6) with the spread of English as the global language, it has been used as lingua franca in different fields such as education, technology, science, business. In this last aspect, English has been used for global negotiations. English is considered a recent lingua franca, since England started colonizing from the end of $16^{\text {th }}$ century but others existed in the past for example, Sanskrit, Greek, Arabic, Portuguese and others.

The term Lingua Franca was considered first as a variety of spoken language along the Mediterranean coast from the fifteen century. It appeared as a pidgin of the Italian dialects and later it included objects from the Arabic, French, Greek, Persian, Portuguese, and other languages from the time. Gorlack (1988: 28) a linguist from Germany, says that structure and lexicon are important items in a language. The simpler the structure the more people like to use the language. Compared to Latin, English is much simpler. Latin has accusative, dative, genitive, feminine and neuter, but English does not have such features.

It is amazing to see steadily English has evolved from very small ethnic groups: Angles and Saxons in the $5^{\text {th }}$ century to the largest area of speaking. It is slowly but surely spreading to the whole world wide. At the end of the $16^{\text {th }}$ century, there were approximately between 5 and 7 million people who spoke English in the world. 350 years later, there are more than 300 million people speaking it as first language, and there are about a billion people who use English as a second language. Graddol (1997:4) has found that 2 billion people are learning English today. 
China has been a powerful global player in the past, and now with its technology as detailed by Maddison (1998:5) in earlier work for the OECD Development Centre, it is contributing as much as nearly a third of world GDP as late as the beginning of the 19th century. Its recovery over the past decade has been spectacular, creating both opportunities and challenges for many other countries, most notably developing countries and emerging economies. For Latin America, China looks more like a "trade angel", as it provides an outlet for commodities from the region. China's trade impact on Latin America is, thus, positive; directly, through a boom of exports, and indirectly, through better terms of trade.

"Language is defined as a vocal system which is used by human beings to communicate with each other. Thus language is more than communication; it's a social action and functions to express thoughts. In most cases, language is a dominant leader and ruler of the dependent. People are also dependent on it" (Finnegan, 1999).

\section{History of English as Communication Tool}

Since communication became necessary, people started to look for and share a common language. According to Crystal (2003:74) a language which was easy to understand and easily handed. A language which due to the number of people who travel and hold on any kind of business in different parts of the world becomes unique. In this way and under various circumstances, English has become the Global Language. It is not because of the number of people who speak it as native language (there are about 350 million people around the world speaking English as a first language and more than 430 million people speaking it as a second language). But why is English so popular, though? And why has it become a global language? Of course there is a History about the evolution of English as a Globalized Language. Starting with early civilizations described in the Bible and the book of Genesis in which people pretended to reach the sky building the highest tower in the world (Babel) and in which God punished them destroying it and starting new languages among which there was English.

On the second approach, Northrup (2013:39) relays his analysis based on the literature left and poetry used in Middle English of Chaucer's Canterbury Tales and the spread to different countries. Then other linguists have put emphasis on the diversity of uses of language such as native speaker vs non-native speaker, description vs perception. Until there was a recent text English -One Tongue, Many Voices which explains the variations of language of native speakers in Britain, The United States and British settler colonies.

In this way Crystal (2003:78) remarks that a language does not exist independently. It is because it exists on peoples' brains and mouths and ears and hands. And when it succeeds, on the international stage, their language succeeds also. That means that the language is a 
living thing that exist if a community exists and needs it to interact between its members. In the postcolonial world, English is often used outside the domestic area, discussions of the links between English and Anglo culture may even seem repulsive. Speakers of English — in Britain, the United States, and elsewhere - discussions of possible links between English and Anglo culture may also seem to be best avoided Quirk (et al. 1985:17).

Since then educators started to teach a Standard English at schools, ruling it especially on pronunciation, vocabulary and syntax, same as all languages go. According to Cristal (2003:62), a standardized English writing form became a powerful tool in the hands of government, church and school in asking the peoples of the British Isles to see themselves as one. On the other hand, migration through slaves or for other reasons, has caused a mixing of different languages, giving origin to pidgins and creoles, which are simplified version of the original language.

\section{Reasons why English is a Global Language.}

\section{English is the Business \& Finance Language.}

From the perspectives described above, English language has turned into a register used for political talks or negotiations, and even into a business language. Scientific and medical researchers also use English according to Crystal (2003:124). There is the need of a global language, particularly appreciated by the international academic and business communities. It means that people use it in lecture rooms and board-rooms as well as it is spread on the biggest net of information (Internet).

Global trade is no longer a matter of bilateral arrangements between nations and states, it is also between organizations economically rooted in these states. These enterprises are called multinational companies. Through the media production Hollywood has become the leader publisher and producer of films for the world, even though there are a lot of regional film markets in other languages such as Spanish, Portuguese, French, German, Chinese, Russian, Hindu. A Blockbuster is a movie that makes a lot of profits (more than a billion dollars) for the producers. Crystal (2003:128) Movies in the early 1910s were still soundless, but then with the introduction of sounds in the movies, it was English the language that was added to the production, especially the ones produced by Hollywood Studios. For example, in 1933 appeared the first edition of The picturegoer's who's who and encyclopaedia of the screen today. Out of 44 studios listed, 32 were American or British (the others were German and French).

By 1945, English became an important language for communication into the United Nations. As Crystal (2003:83) states in his book, The UN has fifty distinct organs and other 
commissions in which their members interact using English as the lingua franca. Today English plays an important role in the proceedings of most major international organizations and political parties such as Association of South East Asian Nations, The Commonwealth, and the Council of Europe.

Northrup (2013:114) recognizes that scientific organizations are also using English only, as well as some sport organizations also use English for their daily activities. In Europe there are institutions such as The European Academy of Anesthesiology and the Academy of Facial Surgery, among others, which use English as the lingua franca. The situation has become serious as more members join the previous big organizations. International Politics operate at different levels and at different ways, using English as the main language.

\section{Simplicity of the English Language.}

Its simplicity, has become English as the major language used in books, and literature. English is used for traveling. According to Crystal (2003:136) English speaking countries are the most affluent regions on this planet, and the amount of people going abroad on overseas holidays have created the phenomenon of English being the common language people with different national backgrounds use to speak with each other. English is the language used for booking a local hotel; restaurant or retail staff members communicate with foreigners and visitors in English.

English has been used in music and the cinema, which were two new entertainment technologies for people which emerged at the end of the nineteenth century, the other one was the recording industry. English is the main language used in recording. When Thomas Edison invented the phonograph, the first recorded words were "What God hath wrought", then it was followed by the nursery-rhyme "Mary had a little lamb". Then, Gramophone American records appeared introducing the first long-play (LP) disk in 1948. English was the language used in those songs. Crystal (2003:142) mentions that radio stations started playing music and the language which was included was English. They testify the dominance of English in the popular music scenery. Music was later exported to other countries and when it arrived, it was entirely in English. Their lyrics became popular and people started singing their favorite songs.

\section{English is the Language of the Internet!.}

According to Unbabel (2017:1) English has always dominated the web. Even today, it's estimated that $55.5 \%$ of all web content is in English. However, around 20\% of the world's population speaks English at all, and just 5\% of the world speaks English as a native language. It makes sense. English was the founding language of the web, after all. People have gone from being passive consumers of content to active creators of it, while online 
retailers have increasingly offered personalized content to attract customers. The importance of the Internet grows rapidly in all fields of human life, including not only research and education but also marketing and trade as well as entertainment and hobbies. This implies that people have to know how to use Internet services and, as a part of this, to read and write English.

Of course, the majority of mankind are not able to use the Internet nowadays or in the near future, since they live in countries which lack the necessary economical and technological infrastructure. Northrup (2013:119) mentions that the Internet causes polarization in developed countries, too: people are divided into Internet users and Internet illiterates, and as the use of the Internet grows and often replaces traditional methods of communication, the illiterates may find themselves in an awkward position.

It is no longer lasting the idea of a global language dominance unless one authority could define an official language for the Internet. The Internet as a whole is not controlled by anyone or anything, and this could only change if, by miracle, all countries made an agreement on it or if the entire world were taken to the control of one government.

\section{Speaking Fluent English Denotes a Certain Social Status.}

Language learning is associated with a range of factors including age, gender, learning strategies, sex, intelligence, motivation, anxiety level and the last is learning style. As Willis (2008:7) states that the more your child knows about the way she learns best, the more insight, strategies, and self-awareness she will have to use her learning strengths to achieve her greatest potential as a joyful learner. With this tool people are offered jobs and business opportunities in China and other developing nations, as well as in a native English speaking country.

Language is instinctively a symbol of status in the global society because of the image it projects forehead. Crystal (2003:169) mentions for example if someone speaks with an intricate and broken English, he will appear as a not well educated person, but if a person who talks largely in a well spoken language, including no mistakes and dressing perfectly, he will appear as a rich person. It gives a social standing which is preferred by business people, or people who are involved in the commerce area.

The $21^{\text {st }}$ century has witnessed a revolution in the use of mobile phones, emails and Internet. Then English communication has become a necessity to stand out of the world. English has also become the language of air transport, shipping and the leading language of science and technology. According to a research conducted by Stockinger (2001:14), secretaries, for 
instance, are expected to be able to hold telephone conversations in English while technicians have to be able to read technical literature in English.

\section{Education .}

Through the expansion of the new theories of teaching, and especially the development of new areas of science and technology, Macaro (2017:2) argues that it has been necessary to find a common language to disseminate knowledge throughout the world. Since the 1960s English has become a normal medium of instruction in higher education for many countries, and Ecuador could not be away from this real situation. People need to be in contact with the latest breakthroughs in science and technology as well as the new advances in medicine.

English language teaching (ELT) business has become one of the major growth industries around the world in the past half-century. In conclusion English will retain its role as the dominant language in the world media and communications. English is essential for progress as it will provide the main means of access to high-tech communication and information over the next 25 years. Nowadays, there are still some barriers between people from different countries, but more and more people are learning English and using it as a Lingua Franca. An example of this is people from Latin America, and people from China. English is been spread rapidly because they need it a language for trading and holding on treatments.

Perhaps the existence of English as a global language for commerce is a product of the imperialism (Panimal, 2013: 4). It has become an international language which bridges cultures and language barriers. Hopefully, someday English will eliminate all communication boundaries worldwide.

\section{Advertising.}

At the end of the nineteenth century, advertising increased dramatically especially with the mass production of goods. In 1893, McClure's Magazine, Cosmopolitan and Munsey's Magazine adopted the tactic to promote different products. A ten-cent magazine was very common and published for many years. Then advertising became a norm. Later some magazines dedicated to produce at least half of the magazine in color. Crystal (2003:197) Until now we have supplements of the principal newspapers which accompany including colorful pictures. During the nineteenth century the advertising slogan became a feature of the medium, "it pays to advertise" itself became a US Slogan in the 1920s. many products have become an international brand now and still keep their advertisements almost the same, such as Coca Cola, Kodak and Kellogg.

\section{The Economical Rise of China .}

According to Lopez (2017:6) the first fact he mentions is the increasing relevance of Latin America's economy. It has woken up an especial interest by Asian Countries and the Chinese market. These countries are interested in having business agreements with Latin American 
Countries (LAC). Latin America is geographically distant from Chinese territory and therefore no wars or disputes between these two groups of people could happen, so on the contrary, they both have developed a good relationship.

The second historical fact to be considered is Chinese immigration to Latin America in the $19^{\text {th }}$ century. They were employed especially in sugar plantation, mining, railway construction. LAC received also some Japanese immigrants by the same time. Hearn, (2013:8) recalls the rise of China compared to Latin American countries. These countries have developed certain reforms, particularly in the area of infrastructure. According to Santiso, (2009:5) Latin America serves as implicit recognition "triangular" relationship among China, the United States and Latin America in which the interests and actions of each party in the region were acknowledged to potentially affect the others.

This interaction, will help to countries of Latin America and also will contribute to the develop and expansion of the English as the global language. Tokatlian (2009:17) "Latin America, China, and the United States: a Hopeful Triangle," the brief essay. China's economic boom represents a major global change. Over the last few years, China has expanded by leaps and bounds and become both a threat to and an opportunity for emerging markets. Its growing demand for raw materials is at the same time a bonanza and a challenge for developing countries.

\section{Growing Relations between China and Latin America.}

Ellis (2011:16) mentions the link between China and Latin America really took off from the late 1990s but only began to attract significant global attention with the visit of the Chinese president, Hu Jintao, to several Latin American countries and to the summit of the AsiaPacific Economic Forum, held in Chile in 2004. It was not until 2008 that the Chinese government issued its first policy paper on Latin America and the Caribbean. The most striking evidence of China's growing involvement in Latin America is the increased level of bilateral trade. Between 1999 and 2008, total trade (exports plus imports) increased almost twelvefold to US\$ 150 billion.

Similarly, Chinese aid, in the form of grants or concessionary loans, has not been very significant in Latin America. This is in marked contrast to Africa, where China has become a major donor. Ganeshan (2012:14) points out the loser economic ties with Latin America have been accompanied by stronger political links. China has signed 'strategic partnership agreements' with Venezuela (2001), Mexico (2003) and Argentina (2004), in addition to an earlier agreement with Brazil (1993). Over the past five years the number of countries in the region that recognize the PRC has increased with the establishment of diplomatic relations with Dominica (2004), Grenada (2005) and Costa Rica (2007). 
Lopez (2009:18) says that Chinese economic relations with Latin America are concentrated on obtaining natural resources and sending manufactured goods to the region. The majority of LAC are becoming important providers of raw materials and energy that are crucial for China's industrialization. For example Brazil exports two-thirds of its soy production and ore mineral. Argentina exports $80 \%$ of its soy and Chilean copper materials are sent to China.

Chinese strategy is becoming successful, when stabling its flow of raw materials from Latin America. China and Brazil have subscribed a ten year-credit-oil agreement with Petrobras, and China has given the loan in Advanced to Brazil. Lopez (2009:20) remarks with this economic background, China appears to be new form of colonialism over Latin America.

China is an emerging power, and since 2010 the second leading economic world power, with special characteristics, due for its population and the strong political regime. China's strategies and business dealings differ according to the Latin Country it is held, and with each LA country, China has sign special agreements. Wignajara (2012:16) mentions that the 1990s are witnessed by the establishment of several economic cooperation agreements, involving Latin American Countries for example the MERCOSUR, the North American Free Trade Agreements (NAFTAs)

While Asian-Latin America FTAs are relatively of recent origin, there has been an expansion of FTA activity between 2004 and 2012. The leader among the South American countries has been Chile (7 FTAs), followed by Peru (4 FTAs) and Panama (2). It is important to recall here that not only China has sign agreements, but also Taipei, Singapore, India, Japan and Korea have some treatments. On the other hand, it is difficult to measure how much a country's economy is covered by FTA provisions because of exceptions and exclusions contained in many agreements.

China's access to Latin American markets has been a source of conflict, particularly in the more industrialized countries of the region. Local manufacturers have complained that they are adversely affected by Chinese competition, and this has led to anti-dumping measures being taken against Chinese goods.

\section{Analysis.}

The expansion of English a lingua franca, has helped on the expansion of borders, and the economically powerful countries have signed agreements for trading goods at different levels. Government enterprises as well as private enterprises are now connected through agreements which are written in the lingua franca, even though each country manages a different language of communication. 
China's rapid economic growth and increased openness has been one of the most significant developments in the global economy over the past three decades. This re-emergence of China dates from the late 1970s, when Deng Xiaoping began the process of reform and economic opening. While Latin America entered a decade of economic stagnation in the 1980s, China was starting a period of rapid economic growth. Since 1980 the Chinese economy has grown at almost 10 per cent per annum, and as a result per capita income has increased sevenfold. China is now poised to overtake Japan as the second-largest economy in the world, behind the United States.

Lopez (2017:4) mentions that it is easy to find analysts, commentators and policymakers in Asia and Latin America voicing concerns about the emergence of the PRC and claiming that the PRC is adversely affecting direct investment flows into their economies. In November 2002, Singaporean Deputy Prime Minister Lee Hsien Loong (who has since become Prime Minister) stated, "Southeast Asian countries are under intense competitive pressure, as their former activities, especially labor-intensive manufacturing, have migrated to the PRC. One indicator of this massive shift is the fact that China has signed many agreements with south American Countries for business, according to KOTRA

TABLE 1. TRADE AGREEMENTS BETWEEN THE COUNTRIES OF SOUTH AMERICA

\begin{tabular}{|c|c|c|c|c|c|c|c|}
\hline & Merco & Bol & Chile & Col & Ecu & Perú & Ven \\
\hline Mercosur & ACE $18 *$ & ACE 36 & ACE 35 & ACE 59 & ACE 59 & ACE 58 & \\
\hline Bolivia & ACE 36 & & ACE 22 & CAN ** & CAN ** & CAN ** & \\
\hline Chile & ACE 35 & ACE 22 & & ACE 24 & ACE 65 & ACE 38 & ACE 23 \\
\hline Colombia & ACE 59 & CAN ** & ACE 24 & & CAN ** & CAN ** & \\
\hline Ecuador & ACE 59 & CAN ** & ACE 65 & CAN ** & & CAN ** & \\
\hline Perú & ACE 58 & CAN ** & ACE 38 & CAN ** & CAN ** & & \\
\hline Venezuela & $* * *$ & & ACE 23 & & & & \\
\hline
\end{tabular}

Taken from: Free Trade Agreements in South America. Trends, prospects and challenges)

\section{Conclusion.}

- The 2008 global financial crisis affected also to South American countries. It made the necessity to look for cooperation and relationship between other economies. LACs started relationship with Asian countries since early 2000s. Private sector and government companies signed some agreements after a long study period, pretending 
to tear down barriers across countries. Then, since 2000s, inter-regional FTAs were hold on. Most of them worked perfectly and fitted necessities, while other FTAs are still under process of stabilization and negotiation.

- The growth of China has had both direct and indirect impacts on Latin America and the Caribbean. These are often complex and difficult issues to analyze from recent changes which have affected the region. They have also created winners and losers both in terms of countries and of sectors and groups within countries. Wignaraja, $\mathrm{R}$ (2012) Some Asia-Latin America FTAs, however, adopt a some cautious approach to liberalization of sensitive regulatory barriers in areas like investment, competition, and government procurement.

- The main challenge for Latin American and Caribbean policy makers is how to respond to the increased competitive strength of China. This is not only an issue for those countries such as Mexico, which face competition from China in export markets, but for all countries as their domestic markets are increasingly subjected to competition from Chinese imports. There will be pressures to respond through protectionist measures against imports from China

- $\quad$ and where evidence exists of dumping by exporters, this is justified.

\section{Referencias bibliográficas.}

1. Altbach, P. (2015). The Imperial Tongue: English as the Dominating Academic Language. International Higher Education, (49).

2. Brandt, J; Adams, N; Ninh, Christina; (et.al.2012). Chinese Engagement in Latin America and the Caribbean: Implications for US Foreign Policy. AMERICAN UNIVERSITY

3. Branner, R. (2002) ,Zitate aus der Medienwelt', Muttersprache 4, 337-359.

4. Crystal, D. (1998). Isaac Pitman: the linguistic legacy. English Today, 14(03), 12. http://dx.doi.org/10.1017/s0266078400010294

5. Crystal, D. (2003). Why English? The cultural foundation. In English as a Global Language (2nd ed., p. 72-85). chapter, Cambridge : Cambridge University Press. doi:10.1017/CBO9780511486999.005

6. Didier, T., Llovet, R., \& Schmukler, S. (2017). International financial integration of East Asia and Pacific. Journal Of The Japanese And International Economies, 44, 52-66. http://dx.doi.org/10.1016/j.jjie.2017.02.004

7. Dorms, D. Roles and Impact of English As a Global Language. University of Birmingham. 2003

8. Ellis, Evan, (2011), Chinese Soft Power in Latin America. Issue 60. $1^{\text {st }}$ Quarter. 
9. Finnegan. E. 1999. Language: its structure and use. 3rd edition. Orlando: Harcourt Brace College Publishers. Retrieved 18 December, 2015.

10. Ganeshan, Wignaraja, (2012). Asia-Latin America free trade agreements: An instrument for inter-regional liberalization and integration.SADBI Working Paper Series, No. 382t

11. Global English: https://www.ukessays.com/essays/linguistics/why-is-englishconsidered-a-global.php

12. Görlach, M., \& Michael, I. (1998). An annotated bibliography of nineteenth-century grammars of English. Amsterdam: John Benjamins.

13. Graddol, D. (1997). The Future of English? A Guide to Forecasting the Popularity of the English Language in the 21st Century(Vol. 29). The British Council. Retrieved from https://doanbangoc.files.wordpress.com/2012/07/the-future-of-english.pdf

14. Hannan, Swarnali, (2017). The Impact of Trade Agreements in Latin America

15. Hearn, A. (2013). China and Latin America: Economy and Society. Latin American Policy, 4(1), 24-35. http://dx.doi.org/10.1111/lamp.12003

16. Jenkins, Rhys. (2010). China's Global Expansion and Latin America. Pag 809-837.

17. Kankaanranta,, A. (2008). Business English Lingua Franca in intercultural (business) communication. Language At Work - Bridging Theory And Practice, 3(4). http://dx.doi.org/10.7146/law.v3i4.6193

18. Kirkpatrick, A. (2012). English as an Asian Lingua Franca: the 'Lingua Franca Approach' and implications for language education policy. Journal Of English As A Lingua Franca, 1(1). http://dx.doi.org/10.1515/jelf-2012-0006

19. Knapp, K \& C. Meierkord (2002). Lingua Franca Communication. Frankfurt am Main: Peter Lang.

20. KOTRA (the state-run trade and investment promotion agency of the Republic of Korea)

21. Leila barbara, m., celani, a. A., collins, h. Y scott, m. (1996) A survey of communication patterns in the Brazilian business context. English for Specific Purposes, 15(1), pp.57-71.

22. Lopez, V. (2017). Chinese Policy toward Latin America: Implications for Japan and the US Retrieved 15 August 2017, from http://gsis.korea.ac.kr/wpcontent/uploads/2015/04/14-1-02_Victor_Lopez_Villafane.pdf

23. Macaro, E. (2017). English medium instruction: Global views and countries in focus. Language Teaching, 1-18. http://dx.doi.org/10.1017/s0261444816000380

24. Maddison, A. (2009) Home Maddison. (2017). Ggdc.net. Retrieved 17 August 2017, from http://www.ggdc.net/maddison/oriindex.htm

25. Montenegro, Claudio E (2011). El efecto de China en el comercio internacional de América Latina. China's effect on Latin America's international trade. Esl teufdeicotso ddee ECchoinnoam...í a/. CV.o El. .3 M8 o- $n \mathrm{~N} t e^{\mathrm{o}} n$ 2e,g Droi,c iMem. Pberree 2ir0a1, 1I.. PSáoglosa. g3a41-368. 
26. Northrup David, 2013. How English became the global language. Palgrave . Mcmillan US.

27. Ojeda, Tahina, (2010) La cooperación sur-sur y la regionalización en América Latina: el despertar de un gigante dormido. Relaciones Internacionales, núm. 15, octubre de 2010.

28. Ostler, N (2005) Empires of the world: A language history of the world. New York: Harper Collins.

29. Parimal, P G. (International Journal for Research in Education. Vol 2, Issue 2. Feb 2013.

30. Reasons why English is the global language. http://englishharmony.com/english-isthe-world-language/

31. Roett, R., \& Paz, G. (Eds.). (2016). Latin America and the Asian Giants: Evolving Ties with China and India. Brookings Institution Press.

32. Santiso, J. (2009). Latin America: The Good Old Days. SSRN Electronic Journal. http://dx.doi.org/10.2139/ssrn.1557115

33. School of international service. December 2012.

34. Seidlhofer, B. (2001). Closing a Conceptual Gap: The case of a Description Of English As A Lingua Franca. International Journal Of Applied Linguistics, 11(2), 133-158. http://dx.doi.org/10111/1473-4192.00011

35. Tokatlian, J. (2001). La Unión Sudamericana: ¿inexorable o contingente?. Desarrollo Económico, 41(161), 139. http://dx.doi.org/10.2307/3455969

36. Unbabel (2017) Top Languages of the Internet, Today and Tomorrow - Unbabel. (2017). Unbabel. Retrieved 17 August 2017, from https://unbabel.com/blog/toplanguages-of-the-internet/ using. The Synthetic Control Method. 2017 International Monetary Fund.

37. Why English is the language of Internet. https://www.english.com/blog/englishlanguage-internet

38. Wignaraja, G., Ramizo, D., \& Burmeister, L. (2012). Asia-Latin America Free Trade Agreements: An Instrument for Inter-Regional Liberalization and Integration?. SSRN Electronic Journal. http://dx.doi.org/10.2139/ssrn.2151818

39. Willis, MD, Judy. 2008. How Your Child Learns Best. Sourcebook. Inc. Naperville, Illinois

Xu, B. 2012. An Analysis of English Business Letters from the Perspective of Interpersonal Function.

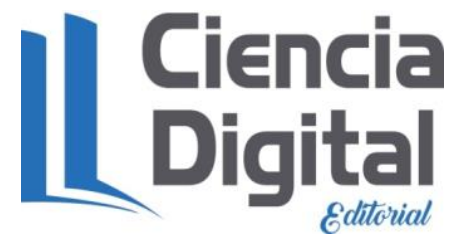




\section{Para citar el artículo indexado.}

Llerena E. (2018). The impact of english as global language for trading between china and south american enterprises. Revista electrónica Ciencia Digital 2(2), 544-560. Recuperado desde:

http://cienciadigital.org/revistacienciadigital2/index.php/CienciaDigital/article/view/118/10 $\underline{9}$

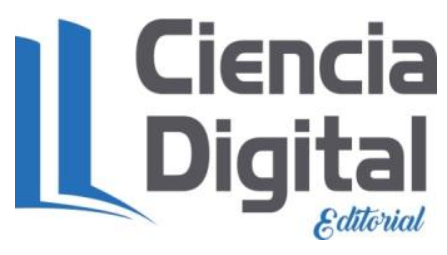

El artículo que se publica es de exclusiva responsabilidad de los autores y no necesariamente reflejan el pensamiento de la Revista Ciencia Digital.

El articulo queda en propiedad de la revista y, por tanto, su publicación parcial y/o total en otro medio tiene que ser autorizado por el director de la Revista Ciencia Digital.
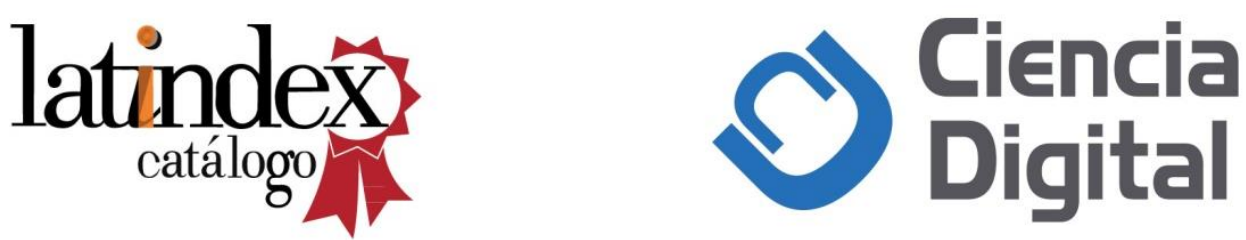